\title{
REKONSTRUKSI PEMIKIRAN HUKUM ISLAM MELALUI INTEGRASI METODE KLASIK DENGAN METODE SAINTIFIK MODERN
}

\author{
Mahsun \\ Universitas Islam Negeri (UIN) Walisongo Semarang \\ e-mail: mahsun_mahfud@yahoo.com
}

\begin{abstract}
This article discusses methodological thinking about integration deals between classical methods with modern scientific methods in a project of reconstruction of Islamic legal thought. The idea of this paper is motivated by the need for the development of Islamic thought, especially in Islamic law. Philosophically, the real emergence manhaji-eclectic method as a result of integration between the classical methods and modern scientific methods is possible. Implementation of the integration must meet the main prerequisites: first, making al-mașlaḥah al-ämmah (public decency) or maqāșid alsharīah as a decisive consideration in seeking a legal aid in three main domains, namely darūriyyah (urgent needs) hājïyyah (normal needs), and tahsininyyah (complementary needs). The second prerequisite, is the emergence of human consciousness that the classical method will not capable to answer the challenges that change dynamically. While the third, is the willingness of people to change to something new and better, as the implementation of al-muhậazazah 'alā al-qadìm al-șăliḥ wa al-akhdh bi l-jadìd al-aṣlah.
\end{abstract}

[

Artikel ini mendiskusikan tawaran pemikiran tentang integrasi metodologis antara metode klasik dengan metode saintifik modern dalam sebuah proyek rekonstruksi pemikiran hukum Islam. Ide tulisan ini dilatarbelakangi oleh kebutuhan pengembangan pemikiran keislaman khususnya pemikiran dalam hukum Islam. Secara filosofis sesungguhnya munculnya metodologi komprehensif dalam wujudnya sebagai metode manhaji eklektis hasil integrasi antara metode klasik dengan metode saintifik modern sangat memungkinkan. Implementasinya, perkawinan dua metode tersebut harus memenuhi prasyarat utama yaitu: pertama, menjadikan al-mașlahah al-'āmmah (kepatutan umum) atau maqāssid al-sharìah sebagai pertimbangan penentu dalam menggali sebuah hukum pada tiga ranah utamanya, yaitu darūriyyah (kebutuhan mendesak), häjizyyah (kebutuhan normal), dan tahsiniyyyah (kebutuhan komplementer. Kedua, adalah munculnya kesadaran manusia akan ketidakcukupan metode klasik untuk menjawab tantangan zaman yang berubah secara dinamis. Ketiga, adalah kemauan manusia untuk berubah menuju sesuatu yang baru yang lebih baik, sebagai implementasi al-muhạfazah 'alā al-qadìm al-șălị̣ wa al-akhdh bi I-jadīd al-aṣlaḥ.

Keywords: rekonstruksi, integrasi, metode klasik, metode modern, maqāṣid alshari’ah 


\section{Pendahuluan}

Tak dapat disangkal, jika naș (teks suci) dikontekstualisasikan terhadap alwāqi' (kenyataan), maka prasyarat yang harus dipahami adalah bahwa keduanya merupakan dua wilayah yang memungkinkan dapat dikawinkan sehingga memunculkan pemahaman yang komprehensif. Ada tiga corak dalam membaca teks menurut al-Shāțibī, yaitu qirā'ah salafiyyah, qirā'ah ta'wīliyyah, dan qirā'ah maqāșidiyyah. ${ }^{1}$ Sementara dalam wilayah al-wāqi' ada beberapa disiplin ilmu yang digunakan dalam memahami fenomena-fenomena sosial, politik dan sebagainya misalnya sosiologi, antropologi, dan lain-lain. Dengan demikian idealnya adalah ketika melakukan pembacaan teks kemudian dikontekstualisasikan dengan fenomena sosial tidak boleh meninggalkan disiplin ilmu yang ada pada wilayah al-wāqi'. Jika tidak demikian, maka pemahaman atas teks tersebut akan out of date dan tidak applicable. Oleh karenanya ijtihad bagi yang mampu melakukannya harus selalu digelorakan dan pintu ijtihad tidak pernah ditutup.

Dalam konteks menggelorakan ijtihād, ilmu ushul fikih merupakan perangkat metodologi baku yang tepat dan telah dibuktikan peranannya oleh para pemikir Islam seperti para Imam mazhab dalam menggali hukum Islam maupun dalam bidang yang lain, dari sumber aslinya (al-Qur'an dan alSunnah). Namun dewasa ini fikih Islam dianggap mandul karena peran kerangka teoritik ilmu ushul fikih dirasa kurang relevan lagi untuk menjawab problem kontemporer. Oleh karena itu, kiranya cukup beralasan munculnya banyak tawaran metodologi baru dari para pakar Islam kontemporer dalam usaha menggali hukum Islam dari sumber aslinya untuk disesuaikan dengan dinamika kemajuan zaman. Metodologi yang dimaksud dapat dihasilkan melalui asimilasi, okulasi, atau simbiosa metodologis.

Kenyataan ini tidak bisa ditolak karena disinyalir bahwa fenomena keangkuhan modernitas dan industrialisasi global telah menghegemoni atau mempengaruhi seluruh lini kehidupan manusia sehingga memicu dinamika pemikiran Islam kontemporer dengan segala perangkat-perangkatnya termasuk metodologi ushul fikih (qawā'id ușūliyyah) dan metodologi pemahaman

${ }^{1}$ Abū Ishāq al-Shātịī, al-Muwāfaqāt (Beirut: Dār al-Ma'rifah, t.th.). 
fikih (qawāid al-fiqhiyyah). Hal ini merupakan pekerjaan besar yang harus dilakukan dalam rangka membangun cita diri Islam (self image of Islam) di tengah kehidupan modern yang selalu berubah dan berkembang secara dinamis. Di Indonesia misalnya, pada dasawarsa terakhir telah muncul gairah perkembangan pemikiran hukum Islam yang sengaja disesuaikan dengan kondisi riil kehidupan di Indonesia. Hal ini dilatarbelakangi oleh kesadaran bahwa fikih klasik dengan perangkat metodologinya secara atomistik ditengarai sudah tidak mampu menjawab persoalan-persoalan kontemporer.

Oleh karenanya, upaya rekonstruksi bangunan teori bermazhab secara manhaji2 adalah sebuah keniscayaan. Usaha itu dilakukan dalam rangka pengembangan pemikiran metodologis menuju -meminjam istilah Qodri Azizi"ijtihad saintifik modern" dengan metode manhaji eklektis ${ }^{3}$ atau manhaji plus saintifik, sebagai implementasi al-muhăfaẓah 'ala 'l-qadìm al-șālih wa 'l-akhdh bi 'l-jadìd al-aṣlah.

Dalam implementasinya, perkawinan dua metode tersebut harus memenuhi prasyarat utama yaitu menjadikan al-mașlaḥah al-âmmmah (kepatutan umum) atau maqāṣid al-sharīah sebagai pertimbangan penentu dalam menggali sebuah hukum pada tiga ranah utamanya, yaitu darūriyyah (kebutuhan mendesak), hājiyyah (kebutuhan normal), dan tahsiniyyah (kebutuhan komplementer). Mengapa, karena pada hakikatnya hukum Islam selalu dibangun atas dasar mewujudkan mașlaḥah. Sementara untuk menilai ada atau tidaknya mașlaḥah pada suatu perbuatan hukum harus selalu memperhatikan kondisi riil. Pada titik inilah kontekstualisasi teks-teks agama dengan perangkat metodologinya menjadi kebutuhan.

\footnotetext{
2Yang dimaksud dengan bermazhab secara manhaji adalah melakukan penggalian hukum secara jamā̄î (kolektif) atau fardī (perorangan) dengan mempraktekkan qawāìd ușūlìyyah (kaidah-kaidah usul fikih) dan qawā'id fiqhiyyah (kaidah-kaidah fikih) oleh para ahlinya. Lihat Mahsun, "Bermazhab Secara Manhaji dan Implementasinya dalam Bahtsul Masail Nahdlatul Ulama Tingkat Nasional", disertasi, (Yogyakarta: UIN Suka, 2013), h. 5. Pada saat tulisan ini dibuat, disertasi sedang dalam proses penerbitan.

3Istilah "eklektis" dipinjam dari konsep tipologi pemikiran Islam al-Jabiri yaitu sebuah tipe pemikiran dalam Islam yang berupaya mengadopsi unsur-unsur yang terbaik dari Barat modern maupun Islam, dan kemudian diramu sedemikian rupa sehingga dapat memenuhi model modernis dan tradisionalis. Lihat: A. Qodri Azizi, Reformasi Bermazhab, Sebuah Ikhtiar Menuju Ijtihad Saintifik Modern (Jakarta: Penerbit Teraju, 2003).
} 
Mahsun

\section{Peran Akal dan Wahyu}

Fitrah manusia sebagai makhluk berpikir dan makhluk berbudaya sekaligus diberikan mandat oleh Allah sebagai khalifah di bumi. Sebagai bentuk tanggung jawab-Nya, Allah memberikan dua alat untuk membimbing manusia dalam menemukan kebenaran. Dua alat yang dimaksud adalah akal dan wahyu. Keduanya diharapkan dapat saling membahu sesuai dengan peran masing-masing secara proporsional.

Akal dengan segala keterbatasan kemampuannya untuk menalar adalah kelebihan yang membedakan antara manusia dan makhluk lain. Al-Qur'an banyak menyerukan kepada manusia untuk berpikir.4 Sebagai khalifah di bumi, manusia diberi kebebasan menggunakan akal pikirnya untuk memakmurkan kehidupan, karena pada hakikatnya manusia adalah makhluk yang berpikir, merasa, bersikap, dan bertindak dan berkecenderungan kepada mencari kebenaran. ${ }^{5}$

Apa yang disebut benar bagi tiap orang tidaklah sama. Oleh karenanya kegiatan proses berpikir untuk menghasilkan pengetahuan yang benar itu pun juga berbeda-beda. Dengan kata lain, setiap jalan pikiran mempunyai apa yang disebut sebagai kriteria kebenaran, dan kriteria kebenaran ini merupakan landasan bagi proses penemuan kebenaran tersebut. ${ }^{6}$ Karena perbedaan kriteria, maka kebenaran baik yang bersifat subjektif maupun yang bersifat objektif sama-sama relatif sepanjang itu dihasilkan melalui proses berpikir. Sebuah kebenaran yang dicapai melalui berpikir sangat ditentukan oleh subjektivitas atau objektivitas dalam berpikir.

Membincang tentang persoalan berpikir objektif sebagai bentuk kerja akal tidak bisa terlepas dari berpikir secara filsafati, karena sesungguhnya filsafat mengajak manusia berpikir menurut tata tertibnya (logika) dengan bebas

\footnotetext{
${ }^{4}$ Ada delapan belas ayat tentang berpikir dengan redaksi yang beragam. Ayat tersebut adalah, alMa'idah: 18, Ali Imran: 191, al-A'raf: 175, 183, al-Nahl: 44, 11, 69, al-Hasyr: 21, Yunus: 24, al-Ra'du: 3, al-Rum: 8, 21, al-Zumar: 42, al-Jathiyah: 12, al-Baqarah: 219, 266, al-An'am: 50, al-saba': 46. Lihat Fayḍullāh al-Hasanī al-Muqaddasī, Fatḥ al-Rạ̣mān li Ṭālib Āyāt al-Qur'ān (Jeddah: al-Haramayn, t.th.), h. 349 .

5Mahsun, "Bermazhab Secara Manhaji dan Implementasinya dalam Bahsul Masail Nahdlatul Ulama Tingkat Nasional".

6Jujun S. Suriasumantri, Filsafat Ilmu, Sebuah Pengantar Populer, cet. XVII (Jakarta: Pustaka Sinar Harapan, 2003), h. 42-43.
} 
(tidak terikat pada tradisi, dogma serta agama) dan dengan sedalam-dalamnya sampai ke dasar persoalan.7 Jadi berpikir secara filsafati yang dimaksudkan adalah berpikir secara mendasar (radic), bebas dan logis tidak terikat oleh nilai apapun termasuk wahyu

Berpikir sebagai kegiatan filsafati individual memang tidak ada sangkutpautnya dengan kehidupan komunal atau sosial, tetapi tidak dapat dipungkiri bahwa implikasi dari hasil sebuah pemikiran akan memasuki pada ranah-ranah kehidupan sosial. Sebagai contoh rekayasa bioteknologi seperti cangkok sperma, kloning, cangkok ginjal babi dan sebagainya dalam tataran sebagai pruduk berpikir adalah sah adanya. Tetapi pada tataran aplikasi tentu (minimal bagi umat Islam) akan mempertanyakan status hukumnya, misalnya bolehkah hal itu dilakukan, bertentangan dengan hukum dan moral agama atau tidak dan sebagainya. Meskipun demikian, jika berpikir terlalu dibatasi dengan norma atau nilai tertentu maka yang terjadi adalah pemasungan fitrah manusia itu sendiri.

\section{Ketidakcukupan Metode-metode Klasik}

Perkembangan pemikiran keislaman dalam sepanjang sejarahnya ${ }^{8}$ telah menunjukkan adanya varian-varian yang khas sesuai dengan semangat zamannya. Varian-varian itu berupa semacam metode, visi, dan kerangka berpikir yang berbeda-beda antara satu pemikiran dengan pemikiran lainnya. Ajaran dan semangat Islam akan bersifat universal (melintasi batas-batas zaman, ras, dan agama), rasional (akal dan hati nurani manusia sebagai partner dialog), dan necessary (suatu keniscayaan dan keharusan yang fitri). Akan tetapi respons historis manusia di mana tantangan zaman yang mereka hadapi sangat berbeda dan bervariasi, secara otomatis akan menimbulkan corak dan pemahaman yang berbeda pula. ${ }^{9}$ Dalam konteks ini, ijtihad ${ }^{10}$ merupakan sesuatu yang tak pernah ditutup tetapi harus selalu digelorakan.

\footnotetext{
${ }^{7}$ Harun Nasution, Falsafah Agama (Jakarta: Bulan Bintang, 1979), h. 10. Juga Franz Magnis Suseno, "Harun Nasution dan Filsafat Agama di Indonesia", dalam Teologi Islam Rasional, Apresiasi terhadap Wacana dan Praksis Harun Nasution, Abdul Halim (ed.) (Jakarta: Ciputat Pers, 2001), h. 125.

8Menurut Nourouzzaman, sejarah adalah peristiwa masa lalu sebagai cermin masa yang akan datang. Lihat: Nourouzzaman ash-Shiddieqiy, Jeram-jeram Peradaban Muslim (Yogyakarta: Pustaka Pelajar, 1998), h. 12. 227.

${ }^{9}$ M. Amin Abdullah, Falsafah Kalam di Era Postmodernisme (Yogyakarta: Pustaka Pelajar, 1995), h.
} 
Dalam konteks menggelorakan ijtihad, ilmu ushul fikih merupakan perangkat metodologi baku yang telah dibuktikan perannya oleh para pemikir Islam seperti para Imam mazhab dalam menggali hukum Islam, dan dalam bidang yang lain, dari sumber aslinya (al-Qur'an dan al-Sunnah). Namun dewasa ini fikih Islam dianggap mandul karena peran kerangka teoritik ilmu ushul fikih dirasa kurang relevan lagi untuk menjawab problem kontemporer, seperti masalah HAM, pluralisme, kesetaraan gender, sepak bola dan tinju wanita, dan masalah-masalah yang timbul dari rekayasa bio-teknologi seperti transplantasi organ tubuh, cangkok sperma, bank sperma, dan sebagainya. ${ }^{11}$ Hal ini memunculkan kesulitan-kesulitan dalam menjawab problem kontemporer.

Kesulitan-kesulitan yang dihadapi pemikiran Islam kontemporer menjadi lebih akut oleh kenyataan bahwa penggunaan metode Muslim klasik tidak dapat dengan mudah menggantikan tugas menanggulangi ketidakcukupan ilmu-ilmu Barat. Ini karena ilmu-ilmu klasik dengan sendirinya tidak memadai untuk mengarahkan aktivitas-aktivitas ilmiah modern. Ketidakcukupan ini telah menjadi sorotan sejumlah pakar Muslim. Al-Faruqi misalnya menyatakan bahwa ketidakcukupan metode-metode tersebut terungkap dalam dua kecenderungan yang saling berlawanan secara diametral. Kecenderungan pertama adalah pembatasan lapangan ijtihad ke dalam penalaran legalistik yakni memasukkan problem-problem modern di bawah kategori-kategori legal, sehingga dengan cara demikian mereduksi mujtahid kepada fäqih (jurist) dan mereduksi ilmu ke dalam fikih. Kecenderungan kedua adalah menghilangkan seluruh kriteria dan standar rasional dengan menggunakan "metodologi yang murni intuitif dan esoteris". 12

\footnotetext{
${ }^{10}$ Ijtihad menurut ulama ushul fikih ialah usaha seseorang ahli fikih yang menggunakan seluruh kemampuannya untuk menggali hukum yang bersifat amaliah (praktis) dari dalil-dalil yang terperinci. Lihat Muhammad Abū Zahrah, Usūl al-Fiqh (Dār al-Thaqāfah, tth.), h. 216. Abu Zahrah, Ushul Fiqih, Edisi terjemahan Saifullah Ma'shum dkk., cet. VIII (Jakarta: Penerbit Pustaka Firdaus, 2003), h. 567. Juga 'Abd al-Wahhāb Khallāf, IIm Ușūl al-Fiqh, cet. XII (Kairo: Dār al-Qalam, 1978), h. 216.

11Menurut Abdillahi Ahmed al-Na'im, hal ini disebabkan oleh adanya kesulitan-kesulitan dalam memadukan pola pemikiran fikih klasik dan fikih kontemporer dalam beberapa hal, antara lain yang berkaitan dengan hukum publik, konstitusionalisme modern, hukum pidana, hukum internasional modern serta Hak Asasi manusia. Baca: Abdullahi Ahmed al-Na'im, Toward an Islamic Reformation: Civil Liberties, Human Rights and International Law (New York: Syracusse University Press, 1990).
}

${ }^{12}$ Ismail R. al-Faruqi, Islamization of Knowledge: General Principles and Work Plan (Herdon, VA: IIIT, 1987), h. 19. 
Keprihatinan serupa juga disampaikan oleh Abdul Hamid Sulayman yang mengaitkan krisis intelektualisme Muslim modern dengan ketidakcukupan metodologis yang menimpa pemikiran Muslim kontemporer, yang memanifestasikan dengan sendirinya dalam penggunaan pola pikir yang semata-mata linguistik dan legalistik. Konsekuensinya, meskipun seorang fäqih (jurist) dididik untuk menangani problem-problem legal spesifik, kenyataannya dia terus dipahami sebagai orang yang serba bisa, intelektual universal yang mampu memecahkan seluruh problem masyarakat modern.13 Akibatnya untuk menjawab problem-problem kontemporer masih selalu mengandalkan informasi dari kitab-kitab klasik secara tekstual tanpa diimbangi kemauan menangkap makna substansinya apalagi metode berpikirnya.

Aspek lain dari ketidakcukupan metode-metode klasik diungkapkan oleh Muna Abu Fadl. Alasan metode klasik tidak memadai, menurutnya, adalah bahwa bila studi fenomena sosial mengharuskan suatu pendekatan holistic yang dengan cara itu relasi-relasi sosial disistematisasikan menurut aturanaturan universal, metode klasik bersifat atomistik yang pada dasarnya disandarkan pada penalaran analogis. ${ }^{14}$ Oleh karenanya, kiranya cukup alasan jika muncul banyak tawaran metodologi baru dari para pakar Islam kontemporer dalam usaha menggali hukum Islam dari sumber aslinya untuk disesuaikan dengan dinamika kemajuan zaman. ${ }^{15}$

Kenyataan ini tidak bisa ditolak karena fenomena keangkuhan modernitas dan industrialisasi global telah menghegemoni seluruh lini kehidupan anak manusia sehingga memicu dinamika pemikiran Islam kontemporer dengan segala perangkat-perangkatnya termasuk metodologi ushul fikih dan qawä'id al-fiqhiyyah. Dinamika yang dimaksud adalah bahwa perlu dilakukan upaya

\footnotetext{
${ }^{13}$ Louay Safi, Ancangan Metodologi Alternatif: Sebuah Refleksi Perbandingan Metode Penelitian Islam dan Barat, terj. Imam Khoiri (Yogyakarta: Tiara Wacana, 2001), h. 20.

${ }^{14}$ Ibid.

${ }^{15}$ Kalau metodologi ulama klasik menitikberatkan pada usaha interpretasi literal al-Qur'an dan alSunnah, maka metodologi baru yang ditawarkan -terutama oleh kelompok liberal-religius- menekankan pada aspek hubungan dialektis antara teks wahyu dengan realitas dunia modern. Hubungan antara teks wahyu dan realitas dunia modern tidak disusun melalui interpretasi literalis melainkan melalui interpretasi terhadap jiwa dan pesan universal yang dikandung dalam teks. Menurut Hallaq, ada dua kelompok yang menawarkan metodologi baru yaitu, Utilitarianisme Religious dan Liberalisme Religious. Lihat Wael B. Hallaq, a History of Islamic Theories (Cambridge: Cambridge University Press, 1997), h. 207, 212, 214.
} 
inkorporasi wahyu ke dalam penelitian ilmiah guna membebaskan sarjanasarjana Muslim dari paksaan epistemologi Barat. Hal ini merupakan pekerjaan besar yang harus dilakukan dalam rangka membangun cita diri Islam (self image of Islam) di tengah kehidupan modern yang senantiasa berubah dan berkembang. ${ }^{16}$ Di Indonesia pada dasawarsa terakhir telah muncul perkembangan pemikiran hukum Islam yang disesuaikan dengan kondisi riil kehidupan di Indonesia. Hal ini dilatarbelakangi oleh kesadaran bahwa fikih klasik sudah tidak mampu menjawab persoalan-persoalan kontemporer.

\section{Korporasi Wahyu dan Metode Ilmiah}

Walaupun kebenaran wahyu itu mutlak, sebagai bukti kebijakan Allah, nabi dan rasul tidak diperbolehkan memaksakan ajarannya (kebenaran) kepada orang lain..$^{17}$ Demikian pula yang menjadi kebiasaan para mujtahid, mereka tidak pernah memaksakan hasil ijtihadnya kepada orang lain untuk mengikutinya, bahkan mempersilahkan meninggalkannya ketika didapatkan hasil ijtihad yang lebih valid.

Pada zaman modern, Islam berada dalam ujian yang sangat berat, khususnya ujian epistemologis. Ilmu ushul fikih yang mestinya dapat berperan sebagai metodologi baku bagi seluruh pemikiran intelektual Islam, dipersempit wilayah kerjanya hanya terbatas dalam bidang hukum Islam. Oleh karenanya sangat beralasan jika dikatakan bahwa kemunduran fikih Islam dikarenakan kurang relevannya perangkat teoritik ilmu ushul fikih untuk memecahkan masalah-masalah kontemporer. Hal inilah yang kemudian menjadikan pekerjaan besar bagi para pemikir Islam untuk merumuskan dan memberikan solusi intelektual terhadap permasalahan tersebut. Al-Jabiri misalnya melihat ada tiga tipologi dalam wacana pemikiran Islam, yaitu modernis ('asraniyyūn, ḥadathiyyūn), tradisionalis (salafiyyūn), dan eklektis (tawfiqiyyūn).18 Menurut al-Jabiri, bahwa tipologi itu terjadi karena terdapat

\footnotetext{
16W. Montgomery Watt, Islamic Fundamentalism and Modernity (London and New York Routledge, 1988), h. 140.

${ }^{17}$ Nurcholish Madjid, Masyarakat Religius (Jakarta: Paramadina, 2004), h. 74.

${ }^{18}$ Kaum modernis ('asraniyyūn, ḥadathiyyūn) menawarkan adopsi modernitas dari Barat sebagai model paradigma peradaban modern untuk masa kini dan masa depan. Sebaliknya, kaum tradisio- 
relasi signifikan pada titik tertentu antara satu konstruksi pemikiran dengan realitas sosial sebagai respon dan dialektika pemikiran terhadap fenomena yang sedang terjadi dan berkembang di masyarakat. ${ }^{19}$

Doktrin ideal yang bersumber dari wahyu Tuhan, ternyata tidak mampu berhadapan dengan ujian yang satu ini sehingga wahyu menjadi tidak dapat "difungsikan" dan "dirasakan" sebagaimana mestinya". ${ }^{20}$ Demikian, agar wahyu ini dapat "difungsikan" dan "dirasakan" sebagaimana mestinya, manusia harus mengerti dan memahami substansi nilai yang terkandung di dalamnya. Manusia harus melakukan apresiasi intelektual atas "doktrin ideal" tersebut yang ditopang oleh kerangka metodologi yang tepat. Prasyarat yang harus ditepati adalah harus ada "kesepakatan" untuk melakukan pemahaman intelektual bahwa agama adalah sistem simbolik yang tidak cukup dipahami sebagai formulaformula abstrak tentang kepercayaan dan nilai saja. ${ }^{21}$

Apresiasi atas agama harus dilakukan pengungkapan makna di balik teks kemudian dilakukan penafsiran. Dari sana akan tergambarkan bahwa Islam adalah ajaran yang dinamis. Dinamisme itu berada di antara Islam Ideal dan Islam Sejarah. Kedinamisan itu terletak dalam ajarannya yang menganjurkan agar akal dapat memahami ayat atau tanda yang terdapat dalam ayat. Di situlah Islam mengenal konsep ijtihad yang digunakan sebagai metode untuk merekonstruksi pemikiran Islam.22 Melalui cara seperti ini seorang mujtahid dapat memastikan posisi akal pikirannya dalam mencampuri hukum Allah. Ini berarti, antara akal dan wahyu harus ditempatkan pada posisi yang proporsional dalam artian bahwa wahyu tidak akan mengebiri akal tetapi akal dalam perannya tidak

nalis (salafiyyūn) berupaya mengembalikan kejayaan Islam masa lalu, sehingga selalu mempertahankan referensi masa lalu sebagai hal yang masih relevan untuk menjawab masa kini. Sedangkan kaum eklektis (tawfiqiyyūn) berupaya mengadopsi unsur-unsur terbaik yang terdapat dalam model Barat modern maupun Islam (masa lalu) serta mempersatukan di antara keduanya dalam bentuk yang dianggap memenuhi kedua model tersebut. Lihat: M. 'Abid al-Jabiri, PostTradisionalisme Islam, terj. Ahmad Basso (Yogyakarta: LKiS, 2000), h. 186.

${ }^{19}$ Muhạmmad 'Ābid al-Jābirī, Ishkaliyyat al-Fikr al-Arabĩ al-Mu'āṣir (Beirut: Markaz Dirāsah aWiḥdah al-'Arabiyyah, 1089), h. 13.

20Mastuhu \& Deden Ridwan, Tradisi Penelitian Agama Islam (Bandung: Penerbit Nuansa Pusjarlit, 1998), h. iii.

21 Ibid, h. iv.

22Ibid. 
boleh melampaui wahyu karena, kebenaran wahyu bersifat mutlak dan kebenaran akal manusia bersifat relatif (nisbi). ${ }^{23}$ Keduanya tidak boleh saling menegasikan tetapi harus berkelindan untuk memberikan solusi terhadap problematika kehidupan. Karena wahyu sebagai teks suci dan problematika sebagai realita pada hakekatnya berasal dari sumber yang sama. Oleh karenanya dalam memahami teks harus tidak boleh terlepas dari konteks.

Hal itu penting, karena kalau kita mencoba mengkontekskan antara naș (teks suci) dan al-wāqi' (kenyataan) maka prasyarat yang harus dipahami adalah bahwa keduanya merupakan dua wilayah yang jika dapat dikawinkan maka akan memunculkan pemahaman yang komprehensip. Corak dalam membaca teks menurut al-Shāṭibī ada tiga yaitu qirā'ah salafiyyah, qirā’ah ta'wïliyyah, dan qirā'ah maqāșidiyyah. ${ }^{24}$ Sementara dalam wilayah al-wāqi' ada beberapa disiplin ilmu yang digunakan dalam memahami fenomena-fenomena sosial, politik dan sebagainya misalnya sosiologi, antropologi, dan seterusnya. Pada wilayah inilah metode ilmiah cukup baik untuk menjadi komandan kajian. Dengan demikian idealnya adalah ketika melakukan pembacaan teks kemudian dikontekskan pada fenomena sosial seharusnya tidak boleh meninggalkan disiplin ilmu dengan segala perangkat metode ilmiah yang ada pada wilayah al-wāqi'. Jika tidak, maka pemahaman atas teks tersebut akan out of date, sehingga tidak applicable.

\section{Peta Pemikiran Hukum Islam di Indonesia}

Di Indonesia, setidaknya ada dua kelompok besar yang terlibat dalam pembahasan tentang pemberlakuan hukum Islam di Indonesia. Dua kelompok itu adalah kelompok yang menekankan pendekatan normatif (formalisme) dan kelompok yang menekankan pendekatan kultural (budaya). Kelompok pertama berpendapat bahwa Islam adalah lengkap, sehingga hukum Islam harus diterapkan kepada seluruh umat Islam untuk dilaksanakan dalam seluruh kehidupan sehari-hari. Sedangkan kelompok kedua berpandangan h. 27.

23Said Agil Husain al-Munawwar, Hukum Islam dan Pluralitas Sosial (Jakarta: Penamadani, 2004),

${ }^{24}$ Lebih jelas lihat Abū Ishạā al-Shātịī, al-Muwāfaqāt.

10 || Volume 25, Nomor 1, April 2015

AL-AHKAM — ISSN 0854-4603 
pentingnya penyerapan nilai-nilai hukum Islam ke dalam masyarakat. Tokoh semisal KH. M.A. Sahal Mahfudh, KH. Ali Yafi dengan pemikiran "Fiqh Sosial" masing-masing adalah termasuk kelompok yang kedua.

Sahal Mahfudh berpendapat bahwa bermazhab secara metodologis (manhaji) merupakan sebuah keharusan, karena teks-teks fikih dalam kitab kuning dipandang sudah tidak applicable seiring dengan berubahnya ruang dan waktu sehingga pemahaman fikih secara tekstual merupakan aktivitas ahistoris dan paradoks dengan problem kontemporer. Menurut Sahal Mahfudh, keniscayaan itu disebabkan bukan hanya karena memahami secara tekstual terhadap teksteks dalam kitab kuning merupakan aktivitas yang ahistoris, tetapi juga paradoks dengan makna dan karakter fikih itu sendiri, sebagai sebuah hasil pemahaman yang tentunya bersifat relatif menerima perubahan. ${ }^{25}$ Adapun prosedur berijtihad/ber-istinbāt secara manhaji (metodologis) menurutnya adalah dengan cara melakukan verifikasi persoalan-persoalan yang tergolong ușūl (pokok/ dasar) dan permasalahan yang termasuk furü' (cabang) dengan terlebih dahulu melakukan klasifikasi apakah termasuk darūriyyah (kebutuhan mendesak), häjïyyah (kebutuhan sekunder), atau tahsininiyyah (kebutuhan tambahan). ${ }^{26}$

Pada tataran aplikasi, Sahal Mahfudh tampaknya sepakat dengan pendapat Maliki dan Hambali dengan konsep al-mașlaḥah al-mursalah dan al-Shāțibī dengan teori maqāșid al-sharīah, yang selalu memandang aspek mașlaḥah sebagai acuan syari'ah dalam ber-istinbat dengan tetap memperhatikan pendapat para shahabat, dan fuqahā' awal. Cara ini ditempuh agar dalam proses penggalian hukum (istinbātt) tidak terjerat ke dalam arus modernitas-liberal semata, tetapi tetap dalam kerangka etik profetik dan frame kewahyuan. Atas dasar pemikiran ini, beliau memberikan tawaran pemikiran "Fiqih Sosial” yang merupakan jawaban alternatif guna menjembatani antara otentisitas doktrin dengan tradisi dan realitas sosial. ${ }^{27}$ Dilihat dari substansi konsep dan semangatnya, tawaran Sahal Mahfudh tersebut nampaknya tidak jauh dengan

\footnotetext{
25Sumanto al-Qurtubi, KH. M.A. Sahal Mahfudh, Era Baru Fiqih Indonesia (Yogyakarta: Penerbit Cermin, 1999). h. 116.

26Ibid, h. 117.

27 Ibid, h. 119-120.
} 
apa yang disebut bermazhab secara manhaji yang diproklamirkan pemakaiannya pada Munas di Bandar Lampung tahun 1992.

\section{Rekonstruksi Metode Bermazhab secara Manhaji: Sebuah Tawaran}

Berbicara tentang upaya melakukan studi rekonstruksi terhadap suatu konsep, tentu yang paling pertama perlu diketahui adalah pengertian rekonstruksi itu sendiri. Rekonstruksi atau reconstructie (Perancis), reconstruction (Inggris) berarti sebuah usaha atau proses pembangunan kembali, penyusunan atau perangkaian kembali. ${ }^{28}$ Dalam sebuah aliran dalam filsafat pendidikan dikenal sebuah teori rekronstruksionisme yang mengatakan bahwa persoalan-persoalan pendidikan dan kebudayaan dilihat jauh ke depan dan bila perlu diusahakan terbentuknya tata peradaban yang baru. ${ }^{29}$ Menurut Hassan Hanafi, rekonstruksi adalah pembangunan kembali warisan-warisan Islam berdasarkan spirit modernitas dan kebutuhan Muslim kontemporer. ${ }^{30}$

Dalam konteks teori-teori tersebut di atas, konsep bermazhab secara manhaji yang telah diputuskan oleh Musyawarah Nasional (Munas) NU sebagai salah satu metode untuk memecahkan masalah-masalah hukum adalah salah satu bentuk produk kebudayaan. ${ }^{31}$ Sementara kaidah-kaidah fikih dan kaidah-kaidah ushul fikih adalah warisan-warisan Islam yang seharusnya dituntut menyesuaikan spirit modernitas dan kebutuhan Muslim kontemporer. Oleh karenanya kiranya perlu dilakukan rekonstruksi agar senantiasa kapabel untuk menjawab problem masa depan. Ini penting dilakukan karena

\footnotetext{
${ }^{28}$ Lihat Bryan A. Garner (ed.), Black's Law Dictionary (USA: West Group, 1999), h. 1278. Juga Osman Raliby, Kamus Internasional (Jakarta: Bulan Bintang, 1982), h. 439. Juga John M. Echols dan Hasan Shadily, Kamus Inggris - Indonesia (Jakarta: Gramedia Pustaka Utama, 1976), cet. XXIII, h. 471.

${ }^{29}$ Ali Mudhofir, Kamus Teori dan Aliran dalam Filsafat dan Teologi (Yogyakarta: Gadjah Mada University Press, 1996), h. 213.

${ }^{30}$ Ia menawarkan ide teologi baru, yakni bahwa teologi tidak sekedar teologi doktriner tetapi lebih merupakan ideologi revolusi ideologis yang dapat memotivasi kaum Muslim modern untuk bereaksi melawan despotisme dan penguasa otoriter. Lebih lanjut lihat tulisan Hassan Hanafi, Mi'n 'l-'Aqïdah il I-Thawrah (Kairo: Maktabah Matbülī, 1991).

${ }^{31}$ Secara ontologis, kebudayaan dapat dipahami sebagai produk dari eksistensi diri manusia, yang meliputi semua aspek kegiatan manusia baik dibidang sosial, politik, ekonomi, kesenian, ilmu, dan teknologi maupun agama. Lihat: Musa Asy'arie, Filsafat Islam tentang Kebudayaan (Yogyakarta: LESFI, 1999), h. 63.
}

12 || Volume 25, Nomor 1, April 2015

AL-AHKAM — ISSN 0854-4603 
teks terbatas sementara permasalahan selalu muncu, ${ }^{32}$ sehingga teks-teks tersebut menjadi tidak cukup memadai untuk menjawab problem-problem kontemporer.

Ketidakcukupan tersebut dapat ditelusur ketika kaidah ushul fikih dan kaidah fiqhiyyah dihadapkan kepada permasalahan yang belum ada ketentuan hukum baik dalam al-Qur'an, al-Sunnah maupun dalam kitab-kitab klasik, sehingga tentu akan tidak mampu untuk dapat menjawabnya. Terhadap masalah asuransi misalnya, ${ }^{33}$ maka akan lebih tepat jika status hukumnya dipertimbangkan dari segi ada atau tidaknya maslahat dan untuk melihat mashlahat itu akan lebih tepat jika dengan melibatkan teori ekonomi yang terkait, tidak melulu dengan kaidah ushul fikih dan kaidah fiqhiyyah, walaupun tanpa harus meninggalkan sikap bermazhab yang telah menjadi komitmen Nahdlatul Ulama.

Secara operasional upaya rekonstruksi metode bermazhab secara manhaji harus selalu memperhatikan aspek maqāșid al-sharīah (tujuan-tujuan syari'at), ${ }^{34}$ sehingga hukum yang didapatkan tidak akan terlepas dari karakteristik dasar hukum Islam yaitu takammul (sempurna, bulat, tuntas), wasațiyyah (imbang), dan harakah (dinamis). Untuk menjawab tantangan dan memecahkan problema masa kini, kiranya sudah saatnya dilakukan rekonstruksi bangunan metode ushul fikih tersebut untuk "dikawinkan" (diintegrasikan) dengan metode saintifik modern agar dihasilkan sebuah keputusan hukum yang applicable. ${ }^{35}$ Integrasi/perkawinan itu dilakukan dengan mengambil elemen-elemen dasarnya, baik dari metode-metode Islam klasik maupun dari Barat modern, karena penolakan secara besar-besaran dan a priori terhadap kedua tradisi adalah tidak ilmiah.

\footnotetext{
32Nasrun Rusli, Konsep Ijtihad As-Syaukani (Jakarta: Logos Wacana Ilmu, 1999), h. 41.

${ }^{33}$ Sistem asuransi sudah dikenal di duni Barat sejak abad ke-14 Masehi sementara di dunia Timur, asuransi baru dikenal pada abad ke-19 Masehi dan ulama mujtahid pencetus kaidah ushul fikih maupun kaidah fiqhiyyah hidup pada sekitar abad ke-2 s. d ke-9 Hijriah. Lihat Hendi Suhendi, Fiqh Muamalah (Jakarta: Raja Grafindo Persada, 2002), h. 312.

${ }^{34} \mathrm{Abū} \mathrm{Isḥāq} \mathrm{al-Shāṭibī,} \mathrm{al-Muwāfaqāt,} \mathrm{Juz} \mathrm{IV,} \mathrm{h.} 529$.

${ }^{35}$ A. Qodri Azizi, Reformasi Bermazhab, Sebuah Ikhtiar Menuju Ijtihad Saintifik Modern (Jakarta: Teraju, 2003).
} 
Elemen dasar yang dimaksud adalah elemen filosofis dan elemen metodologinya pada tataran epistemologis dan aksiologisnya. Dalam tataran filosifis antara metode klasik dan metode saintifik modern sama-sama didesain sebagai alat bantu manusia untuk menemukan kebenaran. Sedangkan secara metodologis keduanya dibangun dari sebuah teori yang mapan dan examineable. Dengan demikian akan ditemukan sisi kecocokan antara keduanya.

Secara skematik perkawinan/integrasi antara metode klasik (qawā'id alfiqhiyyah dan qawā'id ușüliyyah) dengan metode saintifik modern dapat digambarkan sebagai berikut:

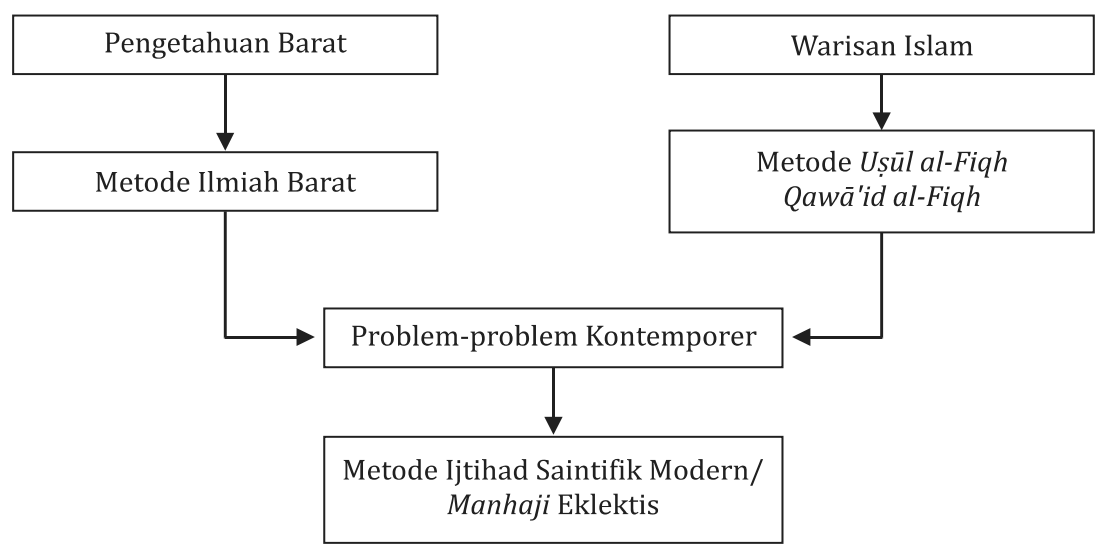

\section{Tugas Masa Depan}

Dengan segala keangkuhan ilmiahnya, metode Barat sesungguhnya memiliki sejumlah kekurangan. Sebagaimana dijelaskan oleh Louay Safi, yaitu pertama, semenjak awal formulasinya dalam karya-karya Francis Bacon dan Rene Descrates, metode modern Barat mengalami bias empirisis yang pada masa kontemporer mencapai puncaknya dengan pendekatan positivistik logis yang dijelmakan dalam behavioralisme Barat. Dengan menggunakan pendekatan positivistik, metodologi Barat bergerak pada tingkat universalitas perbuatan yang disarikan dari masyarakat Barat kontemporer. Cara demikian meningkatkan norma-norma yang terdapat dalam masyarakat modern 
kepada status hukum-hukum universal. Demikian pula metode yang direngkuh sarjana-sarjana Barat menghasilkan hukum dan teori yang bias. Kedua, pada tiga abad terakhir, sarjana Barat secara sempurna "menyingkirkan" wahyu sebagai suatu sumber pengetahuan, dan dengan demikian telah mereduksi wahyu pada tingkat semata-mata sebagai khayalan dan dongeng. Walaupun penyingkiran itu berakar dari konflik sarjana Barat dengan wahyu dalam Injil, kenyataannya penyingkiran itu mempengaruhi ilmuwan-ilmuwan Muslim terpaksa mengadopsi secara berlebihan metode-metode Barat, dan karenanya tidak menjadikan wahyu sebagai sumber pengetahuan. Atau menerima wahyu secara sempurna sehingga cenderung mengorbankan metodemetode modern dan membatasi diri pada metode-metode klasik semata. ${ }^{36}$

Sementara Louay Safi juga melihat bahwa ada tiga faktor keterbatasan mainstream metode tradisional yaitu bersifat legalistik, linguistik, dan terlalu atomistik. Dalam sejarahnya, sesungguhnya telah muncul pemikiran klasik yang berusaha menyeimbangkan mainstream tersebut semisal teori maqāșid al-sharī'ah (tujuan-tujuan syari'ah) yang dikemukakan al-Shāțibì. Teori ini dimaksudkan untuk mensistematisasikan ilmu fikih dan mengimbangi kecenderungan atomistik dalam pemikiran hukum klasik. ${ }^{37}$

Oleh karena itu tugas para ilmuwan Muslim kontemporer adalah menguji metode-metode yang berkembang dalam tradisi Barat maupun Islam untuk menentukan sumber-sumber keterbatasan dan kelebihannya, dan selanjutnya dicari kemungkinan pengembangan dan "perkawinan" antara kedua metode tersebut agar dihasilkan anak metode baru yang komprehensif dan memadahi untuk menjawab problem kontemporer.

\section{Kesimpulan}

Secara filosofis sesungguhnya integrasi metode klasik dengan metode saintifik modern sangat mungkin. Sebagai sebuah upaya rekonstruksi metode bermazhab secara manhaji, perkawinan itu sangat dibutuhkan dalam konteks

36Louay Safi, Ancangan Metodologi Alternatif, h. 10.

${ }^{37}$ Ibid, h. 36. 
pengembangan pemikiran keislaman khususnya pemikiran dalam hukum Islam. Perkawinan itu diharapkan dapat meredam keangkuhan metode saintifik modern dan mencairkan sakralitas metode pemikiran hukum Islam klasik yang tampak statis (untuk tidak menyebut jumud), karena dengan demikian antara keduanya dapat bertegur sapa dan bahkan berdialektika menuju formulasi metodologi baru yang komprehensif. Proses integrasi tersebut, manusia dengan segala mindset-nya menjadi faktor penentu dalam mengasah kreativitasnya untuk membidani lahirnya seorang "bayi" metodologi pemikiran dalam hukum Islam dengan tampilan yang lebih luwes, luas, dan tentunya lebih applicable. [a]

\section{DAFTAR PUSTAKA}

Abdullah, M. Amin, Falsafah Kalam di Era Postmodernisme, Yogyakarta: Pustaka Pelajar, 1995.

Abū Zahrah, Muḥammad, Ușūl al-Fiqh, Dār al-Thaqāfah, t.th.

Abu Zahrah, Ushul Fiqih, edisi terjemahan Saifullah Ma'shum, dkk., cet. VIII, Jakarta: Penerbit Pustaka Firdaus, 2003.

Asy'arie, Musa, Filsafat Islam tentang Kebudayaan, Yogyakarta: LESFI, 1999.

Azizi, A. Qodri, Reformasi Bermazhab, Sebuah Ikhtiar Menuju Ijtihad Saintifik Modern, Jakarta: Penerbit Teraju, 2003.

Echols, John M., dan Hasan Shadily, Kamus Inggris-Indonesia, Jakarta: Gramedia Pustaka Utama, 1976.

al-Faruqi, Ismail R., Islamization of Knowledge: General principles and Work Plan, Herdon, VA: IIIT, 1987.

Garner, Bryan A., (ed.), Black's Law Dictionary, USA: West Group, 1999.

Hallaq, Wael B., a History of Islamic Theories, Cambridge: Cambridge University Press, 1997.

Ḥanafì, Ḥassan, Min al-Aqīdah ilā al-Thawrah, Kairo: Maktabah Matbūlī, 1991.

al-Jābirī, Muḥammad 'Ābid, Ishkaliyyat al-Fikr al-'Arabī al-Mu'āṣir, Beirut: Markaz Dirāsah a-Wiḥdah al-'Arabiyyah, 1089. 
al-Jabiri, M. 'Abid, Post-Tradisionalisme Islam, terj. Ahmad Basso, Yogyakarta: LKiS, 2000.

Khallāf, 'Abd al-Wahhāb, 'Ilm Ușūl al-Fiqh, cet. XII, Kairo: Dār al-Qalam, 1978.

Madjid, Nurcholish, Masyarakat Religius, Jakarta: Paramadina, 2004.

Mahsun, "Bermazhab Secara Manhaji dan Implementasinya dalam Bahtsul Masail Nahdlatul Ulama Tingkat Nasional", Disertasi, Yogyakarta: Universitas Islam Negeri (UIN) Suka, 2013.

Mastuhu \& Deden Ridwan, Tradisi Penelitian Agama Islam, Bandung: Penerbit Nuansa Pusjarlit, 1998.

Mudhofir, Ali, Kamus Teori dan Aliran dalam Filsafat dan Teologi, Yogyakarta: Gadjah Mada University Press, 1996.

al-Munawwar, Said Husain, Hukum Islam dan Pluralitas Sosial, Jakarta: Penamadani, 2004.

al-Muqaddasī, Fayḍullāh al-Ḥasanī, Fatḥ al-Raḥmān li Ṭālib Āyāt al-Qurāan, Jeddah: al-Haramayn, t.th.

al-Na'im, Abdullahi Ahmed, Toward an Islamic Reformation: Civil Liberties, Human Rights and International Law, New York: Syracusse University Press, 1990.

Nasution, Harun, Falsafah Agama, Jakarta: Bulan Bintang, 1979.

al-Qurtubi, Sumanto, KH. M.A. Sahal Mahfudh, Era Baru Fiqih Indonesia, Yogyakarta: Penerbit Cermin, 1999.

Raliby, Osman, Kamus Internasional, Jakarta: Bulan Bintang, 1982.

Rusli, Nasrun, Konsep Ijtihad As-Syaukani, Jakarta: Logos Wacana Ilmu, 1999.

Safi, Louay, Ancangan Metodologi Alternatif: Sebuah Refleksi Perbandingan Metode Penelitian Islam dan Barat, terj. Imam Khoiri, Yogyakarta: Tiara Wacana, 2001.

al-Shāțibī, Abū Isḥāq, al-Muwāfaqāt, Beirut: Dār al-Ma'rifah, ttth.

ash-Shiddieqiy, Nourouzzaman, Jeram-jeram Peradaban Muslim, Yogyakarta: Pustaka Pelajar, 1998.

Suhendi, Hendi, Fiqh Muamalah, Jakarta: Raja Grafindo Persada, 2002.

Suriasumantri, Jujun S., Filsafat Ilmu, Sebuah Pengantar Populer, cet. XVII, Jakarta: Pustaka Sinar Harapan, 2003. 
Mahsun

Suseno, Franz Magnis, "Harun Nasution dan Filsafat Agama di Indonesia", dalam Teologi Islam Rasional, Apresiasi terhadap Wacana dan Praksis Harun Nasution, Abdul Halim (ed.), Jakarta: Ciputat Pers, 2001.

Watt, W. Montgomery, Islamic Fundamentalism and Modernity, London and New York Routledge, 1988. 